Abstracta Iranica

Revue bibliographique pour le domaine irano-aryen

Volume 28 | 2007

Comptes rendus des publications de 2005

\title{
L'animal en islam. Paris, Les Indes Savantes, 2005, 187 p., ill.
}

\section{Pierre Lory}

\section{(2) OpenEdition}

1 Journals

\section{Édition électronique}

URL : http://journals.openedition.org/abstractairanica/12392

DOI : 10.4000/abstractairanica. 12392

ISSN : 1961-960X

Éditeur :

CNRS (UMR 7528 Mondes iraniens et indiens), Éditions de l'IFRI

\section{Édition imprimée}

Date de publication : 15 mai 2007

ISSN : 0240-8910

\section{Référence électronique}

Pierre Lory, «L'animal en islam. Paris, Les Indes Savantes, 2005, 187 p., ill. », Abstracta Iranica [En ligne], Volume 28 | 2007, document 262, mis en ligne le 18 septembre 2007, consulté le 25 septembre 2020. URL : http://journals.openedition.org/abstractairanica/12392 ; DOI : https://doi.org/10.4000/ abstractairanica. 12392

Ce document a été généré automatiquement le 25 septembre 2020.

Tous droits réservés 


\section{L'animal en islam. Paris, Les Indes Savantes, 2005, 187 p., ill.}

\section{Pierre Lory}

Ce livre entreprend de nous montrer l'omniprésence du thème de l'animal dans la culture islamique classique. Il contient une description de la littérature plus particulièrement consacrée aux animaux, des questions liées à la taxonomie (M.H.B.) ou à la nomenclature (J.S.). Des chapitres nourris abordent les questions de pureté et d'impureté notamment à la consommation de la viande (M.H.B.) et celle de l'abattage rituel (M.H.B.), dont les répercussions pour le droit sont bien sûr immenses. Enfin l'insertion de l'animal dans le monde mythico-religieux de l'Islam classique est évoquée dans un chapitre final (C.M.-J.). Où l'on constatera combien le sujet abordé est central, et combien l'étude de l'animal permet de situer l'image que les humains se donnent d'eux-mêmes.

\section{INDEX}

Thèmes : 7. Islam

\section{AUTEURS \\ PIERRE LORY \\ EPHE - Paris}

